\title{
Bedî‘iyyât Şiirlerinin İki Önemli İsmi: Safiyyüddin el-Hillî ve İbn Câbir el-Endelüsî*
}

Mahmut Üstün**

\section{$\ddot{O} z$}

Arap edebiyatında birçok farklı şiir türü bulunmaktadır. Bunlardan birisi de Hz. Peygamber'in methini konu edinen ve her beytinde en az bir tane bedî‘ sanat bulunduran Bedî‘iyyât şiirleridir. Bedî‘iyyâtların konusu, bedî‘ sanatları kullanarak Hz. Peygamber'i övmek olduğu için hem medih hem de ta'lîmî/didaktik temalı şiirlerdir. Her ne kadar bu tür şiirlerin mucidi hususunda çeşitli rivayetler bulunsa da kabul edilen görüş Safiyyüddin el-Hillî olduğu yönündedir. Fakat el-Hillı̂’nin bu türü sistematize ettiği ve şiirde yeni bir yol açtığı hususunda şüphe yoktur. Arap edebiyatında İnhitât dönemi (1258-1798) olarak adlandırılan süre içerisinde ilk örnekleri verilen bedî‘iyyât şiirlerinin yıldızı, Memlükler döneminde parlamıştır. Toplumun beklentisi karşısında belâgata karşı olan ilginin artması, Peygamber konulu methiyelerin fazlalaşması, şairlerin kendi aralarındaki rekabet ve meşhur olma isteği, tevessül vesilesi olarak görülmeleri ve hastalıkları iyileştirmesi gibi etkenlerin bedî‘iyyât şiirlerinin revaçta olmasına ve fazlaca nazmedilmesine sebep olduğu söylenebilir. Bu çalışmada da bedî‘iyyât şiirleri hakkında genel bir sunum yapıldıktan sonra bu türün iki önemli ismi olan Safiyyüddin el-Hillî ve İbn Câbir el-Endelüsî hakkında kısa bilgiler verilmiş ve bedî‘iyyelerinin bazı bölümlerinin çevirisi yapılarak içerisinde kullanılan bedî sanatlar gösterilmiştir. Beyitlerin seçiminde bedî‘iyyâtlarda ele alınan konu çeşitliliği adına her konudan en az bir örnek verilmiştir. Şairlerin bedî‘sanatları nasıl kullandıklarını göstermek için ise bazıları aynı olanlardan, bazıları ise farklı olanlardan seçilmiştir.

Anahtar kelimeler: Arap Edebiyatı, Şiir, Bedî‘iyyât, Safiyyüddin el-Hillî, İbn Câbir el-Endelüsî

\section{Two Important Names of Badî'iyya Poems: Safî al-Dîn al-Hillî and Ibn Jaber al-Andalusi}

\section{Abstract}

There are many different types of poetry in Arabic literature. One of them is Badî‘ 'iyya poems which mention the praise of Prophet and contain at least one

\footnotetext{
* Araştırma makalesi/Research article. Doi: 10.32330/nusha.998083

** Araş. Gör. Dr., Kafkas Üniversitesi, İlahiyat Fakültesi, Temel İslam Bilimleri Bölümü, Arap Dili ve Belâgat1, e-posta: mhmtstn@ hotmail.com Orcid No: 0000-00024902-1051 
badî‘ art in each couplet. Badî‘iyya Poems are both praise and educational/didactic-themed poems since their subject is praising Prophet by using badî ${ }^{`}$ arts. Although there are various rumors about the inventor of such poems, the accepted view is that he was Safî al-Dîn al-Hillî. However, there is no doubt that al-Hillî has systematized this genre and created a new knowledge in poetry. The star of the bedî‘iyyât poems, the first examples of which were given in the period called the Inhitât period (1258-1798) in Arabic literature, has risen in the Mamluks period. It can be said that under favour of expectations of society, the factors such as the increase in interest in rhetoric, the increase in the praise of the Prophet, the competition among the poets and the desire to become famous, the fact poems have been seen as a means of tawassul, and that they have cured diseases have caused the bedî' iyyat poems to be popular and highly recited. In this study, after making a general presentation about the bedî'iyyât poems, brief information was given about the two important names of this genre, Safî al-Dîn al-Hillî and Ibn Jaber al-Andalusi and some parts of their badî‘iyyas were translated and the badî‘ arts used in them were shown. In the selection of couplets, at least one example from each subject has been given in the name of the variety of subjects discussed in the badî'iyyas. In order to show how the poets have used the badî' arts, some of them have been chosen from the same ones and some of them from different ones.

Keywords: Arabic Literature, Poetry, Badî‘iyya, Safî al-Dîn al-Hillî, Ibn Jaber al-Andalusi

\section{Structured Abstract}

The word Badî‘iyya (بديعية -ج- بديعيات) is derived from the root letters b-d-'a (ب), which means "to do it for the first time, to derive it, to reveal it, to be the first to do something, to invent and make a bidat". Derived from the same root letters and being a term of rhetoric, bedî is the name given to the science that includes ways of beautifying the word in terms of expression and meaning and examining its rules, provided that it conforms to the environment and respects the clarity of expression. Based on the word badî‘ The word badî'iyya is the name given to the qasidas which are about the praise of the Prophet and have at least one beautiful art in each couplet.

There are various rumors about who invented the bedî'iyya poems. There are three prominent names. They are Safî al-Dîn al-Hillî, Ibn Jaber al-Andalusi and al-İlbîlî. But the accepted view is that he is Safî al-Dîn al-Hillî. The fact that al-Hilli placed this genre in a certain system, opened a new path in Arabic poetry, set an example for the next ones, and declared himself as the inventor of this genre also support this view.

Badî‘iyyas are both praise poems since their subject is Prophet's praise and educational/didactic poems of the given information about Prophet image and 
contain many badî‘ arts. The period in which the most examples of such poems are given or in other words, the time in which their star has shined is the period of the Mamluks.

Factors such as the increase in the tendency towards rhetoric, the demand for prophetic praise, the competition among poets, the healing of diseases, the fact that they have elements of advice and guidance, being seen as a means of tawassul, the desire of the poets to be famous and the expectation of the society have generally formed the reasons for the verse of the bedî'iyyas in all periods. Being a prophetic praise, having at least fifty couplets, written with bahr albasît, containing at least one literal or spiritual beauty art in each couplet, and having the abbreviation "mîm" with fractions are the main conditions of badî‘iyyas.

One of the two prominent names in such poems is Safî al-Dîn al-Hillî. He was born in the city of Hilla as a child of a rich and noble family and grew up here. It can be said that al-Hillî, who started to deal with poetry when he was only seven years old, and started to write poems in the shadow of tribal wars. Because of that his first poems are elegies. But al-Hilli traveled a lot to Damascus, Egypt, Mardin and other towns because he was engaged in trade. Due to the ongoing conflicts and unrest in Hilla, he left there and settled in Mardin, where he had previously gone on trade. Here he held important positions in the shadow of the Artuqid state. Owing to eulogies he wrote for the sultans, he gained an important place in the palace and received great favors. However, al-Hilli, whose reputation is considered to be his pioneer, is indebted to the badî'iyya that he had written for the Prophet. He has given the name elKâfiyetu'l-Bedî 'iyye fi'l-Medâ'ihi'n-Nebeviyye to his badî‘iyya. He has used a total of 151 diffirent literary arts in his qasida.

Another prominent name in this genre is Ibn Jaber al-Andalusi. He was born in al-Mariyya. He took lessons from the important teachers of the period in al-Mariyya. then he left Andalusia to pilgrimage. The information given about Ibn Jaber's life in the sources is very little and is limited to the travels and stays he made with the poet er-Ru'aynî. For about eleven years following the pilgrimage, they benefited from the scholars they encountered in countries and cities such as Egypt, Hijaz, Damascus, Ba'lebek and Alexandria. Like al-Hillî, İbn Jaber also has gained profit from the praises which he has written to the sultans of the Artuqid state. Although Ibn Jaber has written many didactic poems he became famous for the praise poems which he has written for the Prophet. The name of his famous badî'yya is el-Hulletu's-Siyerâ fì Medhi Hayri'l-Verâ. He has used a total of 50 diffirent literary arts in his qasida. 
The subjects covered in the qasidas of al-Hilli and Ibn Jaber are very similar to each other. However, the way they handle the badî‘ arts and the way they deal with the subjects are quite different from each other. al-Hillî has used badî arts more than Ibn Jaber. But It can be said that Ibn Jaber's poetry is more emotional. Also it can be said that Bedî'iyyat poems have achieved their purpose in general and have made positive contributions to Arabic literature. In other words, with such poems, Hz. The Prophet was praised, the beautiful arts were conveyed to large masses, taught and made permanent. In addition, these poems have been instrumental in the writing of annotations by many people, especially their owners.

\section{Giriş}

Bedî'iyye ç. bedî'iyyât (بديعية -ج- بديعيات) kelimesi, "ilk kez yapmak, türetmek, ortaya çıkarmak, bir işi ilk yapan olmak, icat etmek ve bidat çıkarmak" gibi anlamlara gelen b-d-'a (ب-د) kök harflerinden türemiştir ( İbn Manzûr, h. 1400, c.VIII, s. 6-8; el-Fîrûzâbâdî, 2008, s.103-104). Aynı kök harflerinden türeyen ve bir belagât terimi olan bedî‘ de sözü, ortama uygunluk ve ifade açıklığına riayet etmek şartıyla, söyleyişs (lafzî) ve anlam (manevî) bakımından güzelleştirme yollarını içeren ve kurallarını inceleyen bilime verilen isimdir (Yanık, 2014, s. 77). Bedî‘ iyyât kelimesi ise bedî‘ kelimesinden hareketle, Hz. Peygamber'in methini konu edinen ve her beytinde en az bir tane bedî‘ sanat bulunan kasidelere verilen isimdir (el-Mühendis, 1984, s. 76).

İlk dönemlerde geleneksel kasidenin bir bölümü iken Abbâsîler döneminde müstakil bir tür haline gelen medih şiirleri, ana hatlarıla el-Medhu's-Sâdlk (الددح الصادق/ İffetli Medih) ve el-Medhu't-Tekessubî (الددح التكسبي) Kazanç amaçlı medih) şeklinde iki kısma ayrılabilir. Fakat medih temasını sadece methiye/övgü şiirleri ile sınırlandırmak uygun olmayacaktır. Çünkü farklı amaçlarda nazmedilen mersiye, tasvir, fahr ve hamâse, gazel gibi hemen hemen bütün şiir türlerinde övgü cümlelerine rastlamak mümkündür. Daha çok Câhiliye dönemine ait olguların ele alındığı medih şiirleri, Sadru'l-İslam döneminde önemli ölçüde değişikliğe uğramıştır. Bu dönemde Müslüman şairlerin methiyelerini Hz. Peygamber için nazmetmiş olmaları ise el-Medhu'nNebevî (Nebevî Methiyesi) diye adlandırılan bir türün doğmasına sebep olmuştur. Konusu Hz. Peygamber olan methiye şiirleri de bedî‘sanatlarla yoğrulunca farklı bir hüviyet kazanmış ve bedî‘iyyât adını almıştır (Muhammed, h. 1417, s. 48)

İlk bedî‘iyyât örneğinin kimler tarafından verildiği edebiyatçılar arasında tartışma konusu olmuştur. Bazıları, bu türün mucidinin İbn Câbir (ö. 780/1378) olduğunu, İbn Câbir' in çeşitli sebeplerle Endülüs'ten Doğu'ya gelip Kasîdetu'lBürde'yi dinledikten sonra ona benzer bir şeyler nazmetmek istediğini ve bunun sonucunda da bedî‘iyyât türünü icat ettiğini savunmuşlardır (Mübârek, 1935, s. 169). Bazıları, belağâtı çok iyi kullanan, türe bedî‘iyyât ismini veren ve İbn 
Câbir'den önce yaşayan Safiyyüddin el-Hillî (ö. 749/1348) olduğunu iddia ederken (Zeyd, 1983, s. 59) bazıları ise diğer zikredilen isimlerden daha önce yaşamış olan ve şiirinin her bir beytinde en az bir bedî' sanat kullanan 'Ali b. Osman el-İrbilî (ö. 670/1271) olduğunu ifade etmişlerdir (Dayf, 1965, s.360).

Bedî‘iyyât şiirlerinin mucidi hususunda zikredilen üç ana iddiaya bakıldığında hepsinin doğruluk payı vardır. Fakat en muteber olanı Safiyyüddin el-Hillî'dir. Çünkü onun ismi bu tür şiirler ile özdeşleşmiştir. Nasıl ki kurucusu olmadığ 1 halde sadece sistemleştirdiği için aruz denilince akla ilk gelen isim Halîl b. Ahmed (ö. 175/791) ise bedî‘iyyât denilince de akla ilk gelen isim Safiyyüddin el-Hillî'dir.

Hz. Peygamber'in methini konu edinen şiirlerin kökeni, Sadru'l-İslâm dönemine yani Abdullah b. Revâha (ö. 8/629), Kâ‘b b. Züheyr (ö. 24/645 [?]), Kâ‘b b. Mâlik (ö. 50/670) ve Hassân b. Sâbit'in (ö. 60/680 [?]) methiyelerine dayanmaktadır (Kılıç, 1992, c. V, s. 323-324). Bu medihler de içerisinde birçok lafzi ve manevi bedî'sanat barındırmaktadır. Fakat bu şiirler bedî‘iyyât olarak anılmamışlardır. Çünkü Safiyyüddin el-Hillî ile başladığı kabul edilen ve elBûsîr̂’’nin (ö. 695/1296 [?]) de etkisi olan bu tarz için bazı şartlar belirlenmiştir. Nebevî methiyesi olması, beyit sayısının en az elli olması, basît bahriyle nazmedilmiş olması, her beytinde en az bir tane lafzî veya manevî bedî‘ i sanat içermesi ve revîsinin kesreli "mîm" olması, bedî‘iyyâtların ana şatlarındandır (Sa'd, 2008, s. 6). Fakat daha sonraki dönemlerde bu şartlardan bazılarına uyulmadığı söylenebilir. Ayrıca el-Hillî’nin bu türü nazmetme sebebi olarak rüyasını gösterip bu türün şartlarına değinmemesi, şiirinde el-Bûsîrî gibi $\mathrm{Hz}$. Peygamber ve onun ailesi, ashabı, mucizeleri, savaşları, ahlakı ve nübüvveti gibi konuları işlemesi ve kesralı "mîm" revisini kullanması el-Bûsîrî'nin elHillı̂’yi etkilediğini göstermektedir. Ya da başka bir ifadeyle bu türe benzer şeylerin bir alt yapısı veya öncesinin var olduğunu göstermektedir.

$\mathrm{Bu}$ tür şiirler, hem övgü muhtevalı oldukları için methiye, hem de $\mathrm{Hz}$. Peygamber'in sîreti hakkında bilgi verdikleri ve birçok bedî‘sanatı ihtiva ettikleri için bir nevi ta'lîmî/didaktik şiirler olarak da anılabilirler (Selîm, 1962, c. VIII, s. 177). Bu tür şiirlerin en fazla örneğinin verildiği ya da başka bir ifade ile yıldızının parladığı dönem ise Memlükler dönemidir (er-Receb, 2020, s. 99117).

Belâgata olan yönelimin artması, nebevî medihlere karş1 oluşan rağbet, şairler arası rekabet, hastalıkları iyileştirmesi, öğüt ve irşâd ögeleri bulundurmaları, tevessül vesilesi olarak görülmeleri, şairlerin meşhur olma isteği ve toplumun beklentisi gibi etkenler, genel olarak bütün dönemlerde bedî‘iyyâtların nazmedilme sebeplerini oluşturmuştur (Zeyd, 1983, s. 31-40; Muhammed, h. 1417, s. 429-468 ). 
Bedî‘iyyâtlar'ın nazmedilmesi ise Arap edebiyatına olumlu katkılar sağlamıştır. Örneğin; bu konuda birçok eserin telif edilmesine, bazıları yazarları olmak üzere birçok şârihin yetişmesine, belâgatın gelişmesine, edebî eleştiriye farklı bir alan sağlanmasına ve bu konu hakkında birçok muhtasar eserin kaleme alınmasına vesile olmuştur. Ayrıca bu tür şiirler, ilmi anlamda bedî‘sanatların gelişmesine ve yayılmasına, Kur'ân, hadîs ve farklı dönemlerde nazmedilen şiirlerden ve nesirlerden istişhad edilmesine de olanak sağlamıştır (Zeyd, 1983, s. 183-200).

Bu alanda öne çıkan bedî‘iyyât yazarları, eserleri ve bunlar üzerine yapılan şerhler:

- Safiyyüddin el-Hillî'nin el-Kâfiyetü'l-Bedî'iyye fi'l-Medâ'ihi'nNebeviyye isimli eseri ve Şerhu'l-Kâfiyeti'l-Bedî 'iyye fî 'Ulûmi'l-Belâğa ve Mehâsini 'l-Bedî‘ adlı șerhi,

- İbn Câbir el-Endelüsî'nin el-Hulletü's-Siyerâ fì Medhi Hayri'l-Verâ isimli ve yakın arkadaşı Şehâbeddin Ebû Ca'fer Ahmed b. Yûsuf er-Ruaynî elEndelüsî’nin (ö. 779/1377) Tirâzu'l-Hulle fì Şifâ 'i 'l-Ğulle isimli şerhi,

- 'İzzuddîn el-Mevs1lî’nin (ö. 789/1387) Bedî̀iyyetü’l-Mevsllî isimli eseri ve et-Tevessul bi 'l-Bedî' ilâ Tevessül bi 'ş-Şefí' adlı şerhi,

- Zeynüddin Şa‘bân b. Muhammed b. Dâvûd el-Âsârî’nin (ö. 828/1424) el-Bedî 'iyyetü'l-Kübrâ adıla da bilinen el- 'İkdü'l-Bedî̀ 'fì Medhi 'ş-Şefî' isimli eseri,

- İbnü'l-Mukrî el-Yemenî’nin (ö. 837/1433) el-Cevâhirü'l-Lâmi'a fî Tecnîsi'l-Ferâ'idi'l-Câmi 'a li'l-Me 'âni'r-Râ'i 'a adlı eseri,

- İbn Hicce el-Hamevî'nin (ö. 837/1433) Bedî 'iyyetü İbn Hicce elHamevî adlı eseri ve Hizânetü'l-Edeb ve Ğayetü'l-Ereb isimli şerhi,

- Celâleddin es-Süyûtî’nin (ö. 911/1505) Nazmu'l-Bedî‘ fî̀ Medhi Hayri Şefí 'adli eseri,

- Âişe el-Bâûniyye'nin (ö. 922/1516) el-Fethu'l-Mübîn fî Medhi'l-Emîn adll eseri,

- Abdülganî en-Nablusî’nin (ö. 1143/1730) Nesemâtü'l-Eshâr fî Medhi'n-Nebiyyi'l-Muhtâr adlı eseri ve Nefehâtü'l-Ezhâr 'alâ Nesemâti'lEshâr isimli şerhi şeklinde suralanabilir (Zeyd, 1983, s. 170-178; Kılıç, 1992, c. V, s. 323-324).

\section{Safiyyüddin el-Hillî}

Künyesi Ebû'l-Mehâsin (Ebû'l-Fazl, Ebû'l-Berekât) olan Abdülazîz b. Serâyâ b. Alî b. Ebî'l-Kâsım es-Sinbisî et-Tâî olan Safiyyüddin el-Hillî, 
Rebîulâhir ayının beşinde 677 (1278) yılında Kûfe ve Bağdat arasında bulunan Hille şehrinde, zengin ve soylu bir ailenin çocuğu olarak dünyaya gelmiş ve burada yetişmiştir (ez-Ziriklî, 2002, c. IV, s. 17-18).

Henüz yedi yaşındayken şiirle uğraşmaya başlayan el-Hillı̂’nin şair olarak ismini duyurduğu şiirlerini, kabile savaşları gölgesinde nazmettiği söylenebilir. el-Hillî, Mehâsinoğulları ile Ebü'l-Fazloğulları arasında cereyan eden Hille'ye hâkim olma mücadelesinde kaybettiği dayısı Safiyyüddin b. Mehâsin için mersiyeler, karşı tarafı yeren hicivler ve intikama teşvik edici birçok şiir nazmetmiştir. Safiyyüddin el-Hillî, ticaretle uğraştığı için Şam, Mısır, Mardin ve diğer beldelere çokça seyahat etmiştir. Hille'de devam eden çekişmeler ve huzursuzluklardan dolayı oradan ayrılmış ve daha önceden ticaret vesilesiyle gitmiş olduğu Mardin'e yerleşmiştir. Bölgede hüküm süren Artuklu meliki II. Necmeddin Gazi ile irtibat kurmuş ve Dîvânü'r-resâ'il kâtibi olarak Artuklular'ın hizmetine girmiştir. Bu dönemde el-Hillî’nin Artuklu melikleri için nazmetmiş olduğu yirmi dokuz kasideden oluşan ve Artûkiyyât, elMahbûkât ya da el-Kasâ 'idu'l-Artukiyye olarak bilinen eseri, kendisi tarafindan "Dureru'n-Nuhûr fì Medâ'ihi'l-Melik Mansûr" olarak isimlendirilmiştir (Akçay, 2021, s. 56-66). Sultanlar için nazmetmiş olduğu methiyeler sayesinde sarayda önemli bir yer edinmiş ve büyük ihsanlara nail olmuştur (Zeyd, 1983, s. 71-72; Kılıçl1, 1998, c. XVIII, s. 41-44). Dolayısıyla el-Hillî’nin kendisini ispatladığı ikinci şiir türünün ise methiyeleri olduğunu söylemek yanlış olmayacaktır.

Fakat el-Hillî, namını öncüsü olarak kabul edilen Hz. Peygamber için nazmetmiş olduğu bedîiyyesine borçludur. Kur'ân-1 Kerîm'i, meşhur şairlerin şiirlerini ezberlemiş olması ve Eyyûbiler dönemi önemli şairlerden biri olan elKâdî el-Fâzıl'ın (ö. 596/1200) es-San 'atu'l-Lafziyye (Metinde esas önemin içerikten ziyade şekle verildiği ekoldür. Bu tarzın en önemli özelliği ise beyân ve bedî‘ ilminin kullanılmasında oldukça fazla mübalağa yapılmasıdır.) üslubunu benimsemiş olması, Hillı̂’ye şiirlerinde ş̧ekil ve muhteva bakımından zenginlik ve çeşitlilik imkânı sunmuştur. "Asrının şairi" olarak da bilinen, halk şiirinde bazı yenilikler yapan ve "muzammen" denilen yeni bir muvaşşah türünü de icat eden el-Hillî, İbn Nübâte el-Mısrî' den (ö. 768/1366) sonra döneminin en büyük şairi sayılmıştır (Kılıçlı, 1998, c. XVIII, s. 41-44). el-Hillî, şiirlerinde ğarîb kelimelerden uzak durmuş, lafızlarını sade, ince ve keskin olanlardan seçmiştir. Ayrıca bazı kaynaklarda onun şiirlerinin mana bakımında tatlı, makâsıd bakımından ise fırlatılmış bir ok ve kınından çıkmış bir kılıç misali olduğu zikredilmiştir (el-İ́skenderî vd, 1936, 239; el-Kütübî, 1973, c. II, s. 335). 


\section{1. el-Kâfiyetü'l-Bedî‘'iyye fi'l-Medâ'ihi'n-Nebeviyye}

el-Kâfiyetü'l-bedî'iyye fi'l-Medâ'ihi'n-Nebeviyye isimli bu eser, elHillî’'nin, Hz. Peygamber'i çeşitli bedî‘ sanatları ile övmek üzere kaleme aldığı 145 beyitlik kasidesidir. Kasidesinde birbirinden farklı 140 ama farklı cinâs çeşitleri de ayrı ayrı olarak sayılırsa toplamda 151 edebî sanat kullanan el-Hillî, bu eseri yazma sebebini şöyle dile getirmiştir: "Bütün âlimlerin kitaplarından hangisini buldu isem topladım ve eski şairlerden de keşfettiğim şeyleri bunlara ekledim. Her ne kadar mümkün olmasa da bedî‘sanatların tamamını kapsayan bir eser telif etmek istedim. Ancak bir hatalığa yakalandım, hastalığın süresi uzadı ve şiddeti arttı. O zamanlarda rüyamda Hz. Peygamber'den kendisini methetmemi istediği ve onun sayesinde hastalıktan kurtulacağımı vaat eden bir risale gördüm. Bu yüzden kitap yazmaktansa içerisinde çeşitli bedî ‘ sanatları bulunduran kaside nazmetmeyi tercih ettim" (el-Hillî, 1992, s. 54).

el-Hillî, el-Kâfiyetü'l-Bedî'iyye fi'l-Medâ'ihi'n-Nebeviyye ismini verdiği bu meşhur bedî'iyyesine en-Netâ'icü'l-ilâhiyye fì Şerhi'l-Kâfiyeti'l-Bedî 'iyye olarak da anılan Şerhu'l-Kâfiyeti'l-Bedî 'iyye fì 'Ulûmi'l-Belâğa ve Mehâsini'lBedî` isimli bir şerh yazmıştır. $\mathrm{Bu}$ şerhinde her beyitte kullandığ 1 bedî‘ sanatların daha kolay anlaşılabilmesi için ayetlerden, hadislerden ve klasik şiirlerden örnekler vermiştir. Şerhinin son kısımlarında ise muhtemelen bedî'iyyesini nazmetmeye karar vermeden önce toplamış olduğu belâgat ve bedî‘ ilimlerine dair yazılmış olan yetmiş eseri müellifleriyle birlikte zikretmiştir (Zeyd, 1983, s. 73; Kılıçl1, 1998, c. XVIII, s. 41-44).

Kasidesine klasik bir üslupla başlayan, Hz. Peygamber'e ve onun diyarına olan özlemini dile getiren el-Hillî, daha sonra Hz. Peygamber'e mucizelerini de zikrederek övgüler dizmiş, ashabı ve gazvelerde gösterilen başarıyı dile getirmiş, tekrar Hz. Peygamber'in ahlakını övmüş, ecdadının ve Ehl-i Beyt'in öneminden bahsetmiştir. Son kısımlarda ise bu kasidesini yazma sebebini zikrederek şefaat dilemiştir. Türkçeye de çevrilen (Suzan-Yavuz, 2018, s. 2644) el-Hillı̂’nin bu meşhur bedî‘iyyesinin bazı bölümleri şöyledir:

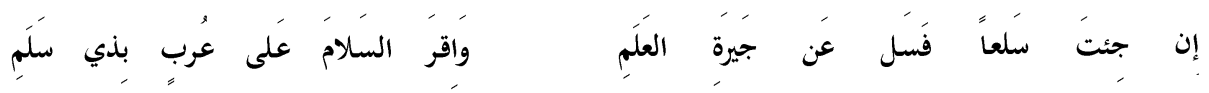

Ĕger Sel'a'ya varırsan, Cîretu'l-'Alem'dekileri sor ve Zû Selem'deki Araplara selam söyle.

el-Hillî, bedî‘iyyesine kulağa hoş gelen, dile ağır gelmeyen, kapalılıktan uzak ve ortama uygun sözlerle güzel bir başlangıç yapmak anlamına gelen Berâ'at-i Matla '/Hüsn-i İbtidâ' sanatını kullanarak başlamıştır. Bu sanatta dikkat edilmesi gereken diğer bir husus ise konuya giriş mahiyetinde olan bu kısımda hangi konudan bahsedileceğinin açıkça zikredilmeyip işaret yoluyla hissettirilmesidir (Bulut, 2015, s.130). el-Hillî de geleneksel kaside formatında olan giriş bölümünde Medine ve Hz. Peygamber'in kabrine yakın olan yerlerin 
ismini uygun bir şekilde zikrederek sanatın şartlarını yerine getirmiştir (el-Hillî, 1992, s. 57).

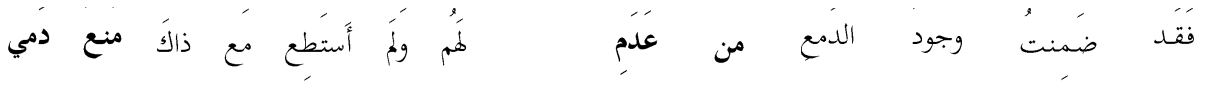

Onlar için gözyaşının olmadiğına emindim fakat gözyaşı ile birlikte kanlısına bile mâni olamadım.

Burada kullanılan sanat Cinâs-ı Telfik/Müleffak'tır. Bu türün şartı, cinâs1 oluşturacak her iki tarafın da ikişer lafızdan oluşmasıdır. el-Hillî, bu sanatı her iki şatrın da son tef'ilesinde uygulamıştır (el-Hillî, 1992, s. 62).

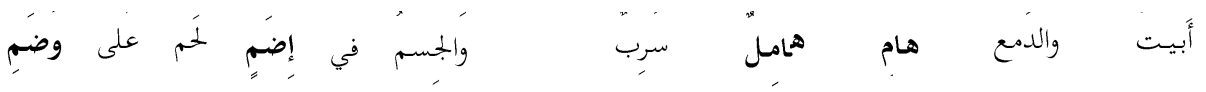

Beden İdam'da kasap tezgâhında bir et gibi, Gözyaşı ise akar, dolup taşar, sizar bir haldeyken geceliyorum.

el-Hillî, bu beyitinin birinci şatrında, cinâsa girecek kelimelerden her hangi birinin son harflerinden en az birinin fazla olması anlamına gelen Cinâs- $\iota$ Müzeyyel/Müreffel, ikinci şatrında ise cinâsı meydana getirecek olan lafızlarda bulunan harflerden en az birisinin türünün ve mahrecinin farklı olması anlamında kullanılan Cinâs-ı Lâhik türü olmak üzere iki cinâs çeşidini kullanmıştır (el-Hillî, 1992, s. 63).

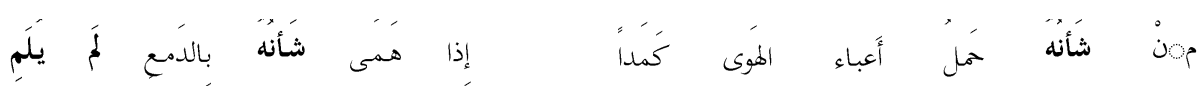

İşi hasret sıkıntılarını keder olarak yüklenmek olan kişi, gözyaşları akıtsa da kinanmaz.

el-Hillî, bu beytinde de iki cinâs çeşidini kullanmıştır. Bunlardan birincisi شَأنَُُ kelimelerinde görüldüğü üzere bütün yönleriyle birbirine benzeyen Cinâs-ı Hakîkî veya Cinâs-ı Kâmil olarak da anılan Cinâs-ı Tâm'dır. Diğerinde

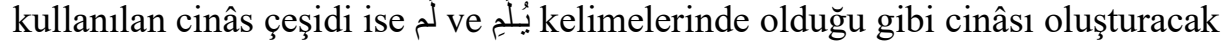
lafızlardan birisinin son harfinin fazla olması anlamına gelen Cinâs-ı Mutarref 'dir (el-Hillî, 1992, s. 64).

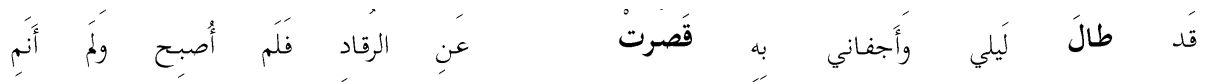

Gecem uzadı ve göz kapaklarım ise uykuya ulaşamad, ne uyanıktım ne de uyudum.

$\mathrm{Bu}$ beyitte kullanılan sanat ise anlam yönünden aralarında zıtlık bulunan iki kelimenin bir arada uyum içerisinde kullanılması anlamına gelen Tibâk'tır. İsmin isme, fiilin fiile veya harfin harfe olan zitlıkları gibi birçok çeşidi bulunan bu türün beyitte kullanılan örneği, fiiller arasında olan zitlıktır (el-Hillî, 1992, s. 72). 


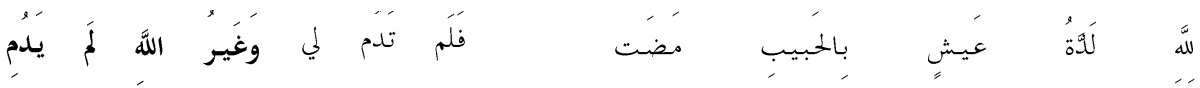

Sevgili ile geçen günler ne de güzeldir! Ama onlar benim için devam etmedi, çünkü Allah dlşındaki hiçbir şey devam etmez.

Burada kullanılan sanat, biten bir cümleden sonra tekit amaçlı bir cümlenin daha zikredilmesi anlamına gelen Tezyîl sanatıdır (el-Hillî, 1992, s. 77).

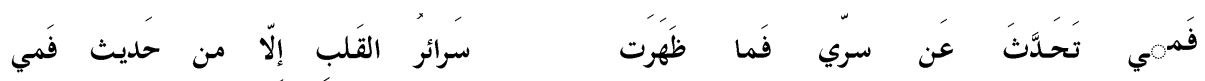

A ̆gzım sırrımı söyledi, kalbin sırları ise ăgzımın konuşması (gevezeliği) dışında açı̆̆a çıkmaz.

el-Hillî, burada "sonu başa döndürmek" şeklinde bilinen ve şiirde beytin sonunda yer alan kelimeyi veya kelimeleri önceden tekrarlamak anlamında kullanılan Reddü'l- 'Acüz 'alâ's-Sadr sanatını kullanmıştır (el-Hillî, 1992, s. 82).

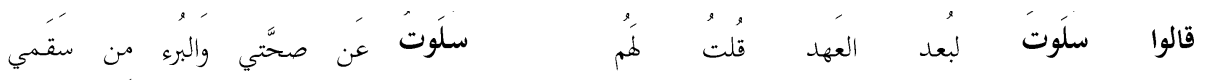

Dediler ki: Ahdin uzamasindan dolayı unuttun (onu) dedim ki: Asıl ben sağlı̆̆ımı ve hastalı̆̆ımdan kurtulmayı unuttum.

$\mathrm{Bu}$ beyitte ise başkasının sözüne karşıllı cevap mahiyetinde bir söz söylemek anlamında olan ve karşıdaki kişinin iddiasının aslında yanlış olduğunu bildirmek anlamında kullanılan el-Kavlu bi'l-Mûceb sanatı kullanılmıştır (el-Hillî, 1992, s. 96).

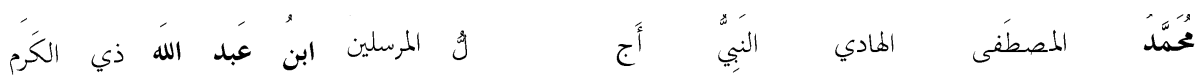

(O), Muhammed el-Mustafâ, el-Hâdî, nebi, elçilerin en yücesi ve kerem sahibi Abdullah' in oğludur.

el-Hillî, kasidesinin bu beytinde bir kimsenin ismini ve ecdâdını büyükten küçüğe veya küçükten büyüğe araya başka isim sokmadan sirasıyla zikretmek anlamında kullanılan İttirâd sanatını kullanmıştır (el-Hillî, 1992, s. 132).

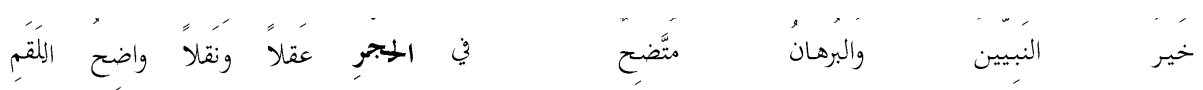

Nebilerin en hayırlisıdır, bunun delili de Hicr'de aklen ve naklen ayan beyandır, aşikârdır.

Burada ise yakın ve uzak anlamı bulunan bir lafzın akla ilk gelen yakın anlamının değil uzak anlamının kastedildiği sanat olan Tevriye kullanılmıştır. Hicr kelimesi ile Hicr şehri değil Hicr suresinde Hz. Peygamber'e verilen müjdeler kastedilmiştir (el-Hillî, 1992, s. 135). 


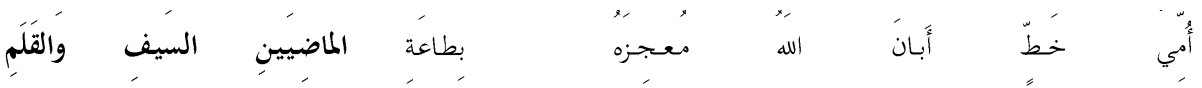

Yüce Allah'ın iki keskin şey olan kilıç ve kaleme itaat etmesiyle mucizesini açık ettiği ümmidir.

$\mathrm{Bu}$ beyitte de cümleyi tesniye bir lafizla bitirdikten sonra onu birbirlerine atfedilmiş iki ifadeyle açılamak anlamına gelen Tevşı̂ ' sanatı kullanılmıştır (elHillî, 1992, s. 139).

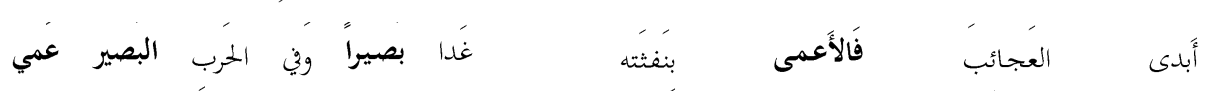

$O$, mucizeler göstermiştir, kör onun tükürügüule gören olmuş, savaşta ise gören kör olmuştur.

el-Hillî bu beyitte bir cümle ya da mısradaki kelime gruplarının ters çevrilerek yer değiştirilmesi neticesinde yeni bir ifadenin oluşması anlamına gelen Tard veya Tebdil olarak da anılan Aks sanatını kullanmıștır (el-Hillî, 1992, s. 145).

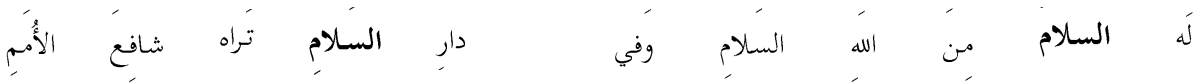

es-Selam olan Allah'tan ona selam vardır, O'nu Dâru's-Selâm'da ümmetlerin şefaatçisi olarak görürsün.

Burada kullanılan edebî sanat, bazı kaynaklarda Mücânese veya Taattuf diye de isimlendirilen Terdîd sanatıdır. Bu sanatta amaç aynı lafzı manasında bir değişiklik olmaksızın farklı konumlarda kullanabilmektir (el-Hillî, 1992, s. 148).

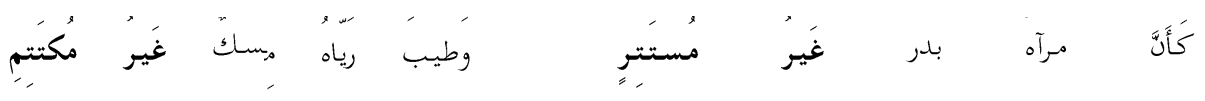

Onun görüntüsü, örtülemeyen dolunay, güzel kokusu ise gizlenemeyen misk gibidir.

$\mathrm{Bu}$ beyitte ise kendisi olmasa bile anlamın bozulmadığı fakat yanlış anlaşılmaya mahal vermemek veya güzel bir şeye teşvik etmek amacı ile kullanılan bazı kaynaklarda İşbâ ${ }^{\prime}$ diye de tanımlanan Îğâl sanatı kullanılmıştır (el-Hillî, 1992, s. 156-157).

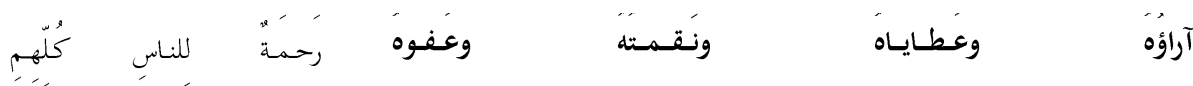

Onun düşünceleri, hediyeleri, gazabı ve affi, bütün insanlar için bir rahmettir. 
Burada kullanılan sanat, birden fazla şeyi tek hüküm altında toplamak anlamına gelen $\mathrm{Cem}^{\prime}$ 'sanatıdır. Hz. Peygamber'in çeşitli halleri, insanlar için rahmet olma hükmünde toplanmıştır (el-Hillî, 1992, s. 166).

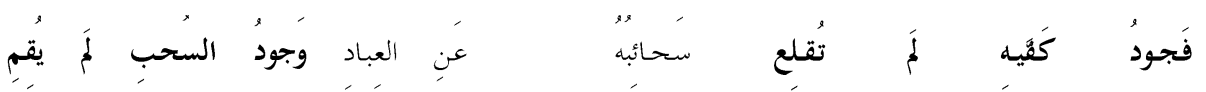

Bulutların cömertliği devam etmediği halde, Onun avuçlartyla yaptı̆̆ cömertliğin bulutları kulları terk etmedi.

el-Hillî, bu beyitte aynı türden olan iki durumun aslında aynı olmadığını ve aralarında fark olduğunu anlatmak için kullanılan ve Tefrîk diye isimlendirilen sanatı kullanmıştır. Yani iki bulutun cömertliği zikredilmiş fakat birisi devam ettiği halde birisinin kesildiği dile getirilmiştir (el-Hillî, 1992, s. 167).

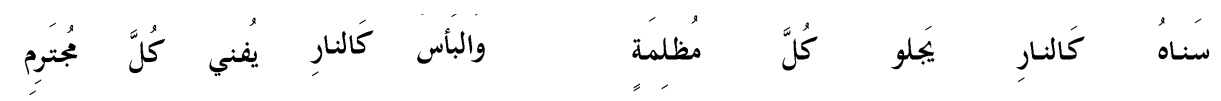

Onun ışığı, ateş gibidir her karanlığı aydınlatır, cesareti de ateş gibidir her mücrimi yok eder.

Burada ise iki şey arasında cem yapıldıktan sonra ayrım yapmak anlamında kullanılan Cem ' me 'a't-Tefrîk sanatı kullanılmıştır. Yani Hz. Peygamber'in 1şığı ve cesareti ateşe benzetildikten sonra bu ateşlerin farkı dile getirilmiştir (el-Hillî, 1992, s. 170).

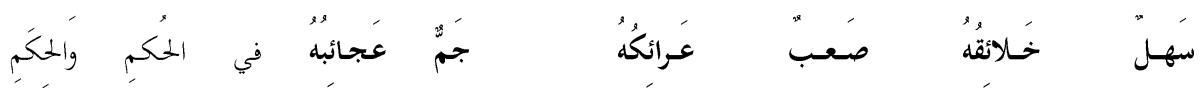
olandir.

O ahlakr güzel, mizacı zor, hüküm ve hikmet hususunda mucizeleri bol

$\mathrm{Bu}$ beyitte kullanılan sanat ise lafizların çoğunun veya hepsinin vezin yönünden uyması anlamına gelen Mümâsele sanatıdır. Beyitte görüldüğ̈u üzere

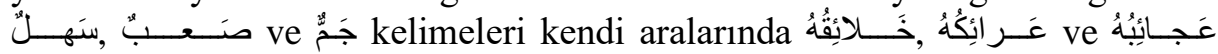
ifadeleri de kendi aralarında vezin yönünden uyumludurlar (el-Hillî, 1992, s. 195).

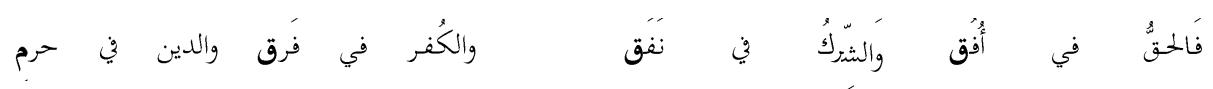

Hak ufukta, şirk yer altındadır, küfür korku içinde, din ise Mekke'dedir.

el-Hillî, bu beyitte Tesmît de denilen Müsemmat sanatını kullanmıştır. Bu sanatın gereği ise ilk üç kısmın kafiyesinin aynı, dördüncü kısmın kafiyesinin kasidenin kafiyesi ile uyumlu olacak şekilde bir veya iki beytin dört kısma bölünmesidir (el-Hillî, 1992, s. 196).

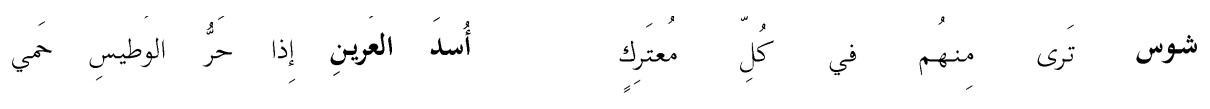


Onlar (sahâbeler), cesurdurlar, çarpışma kızıştığında onları her savaşta inlerindeki aslanlar gibi görürsün.

Burada kullanılan sanat da insanın başka bir varlığa hitap ederek kendisini kastetmesi anlamına gelen Tecrîd sanatıdır. Fakat el-Hillî burada kendisini değil aslanların cesaretini zikrederek sahabeleri kastetmiştir (el-Hillî, 1992, s. 207).

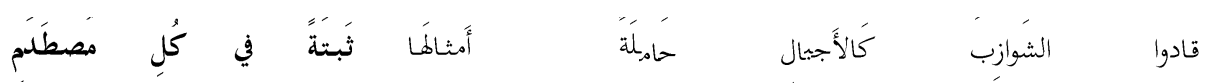

Onlar, bütün çarpışmalarda sabit olan dağlar gibi sert ve kuru olanları binek olarak kullandilar.

$\mathrm{Bu}$ beyitte kullanılan edebi sanat ise sözün sonrası olmağı zaman bir şüphe veya kapalılığa mahal vermemek için açılama yapmak anlamındaki $\hat{I} z a ̂ h$ sanatıdır (el-Hillî, 1992, s. 214).

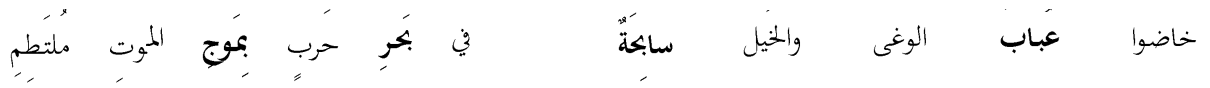

Atlar, ölüm dalgaları ile dalgalanan bir savaş denizinde yüzerken onlar savaş sellerine daliyorlar.

el-Hillî burada I'tilâf sanatını kullanmıştır. Bu sanattaki amaç sözün etkisini artırmak için birbiri ile uyumlu olan kelimeleri bir arada kullanmaktır. Farklı çeşitleri bulunan I'tilaf sanatının burada ele alınan türü ise I' tilafu'l-Lafz me 'a'l-Lafz diye anılan lafzın lafza olan uyumudur (el-Hillî, 1992, s. 226-227).

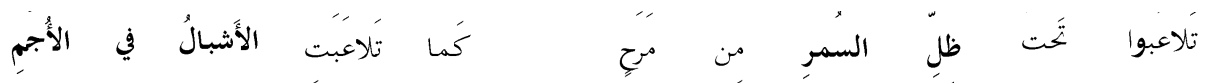

Onlar mutluluktan çalılıklar arasında oynayan aslan yavruları gibi, mizrakların gölgesinde oynuyorlar.

Bu beyitte ise iki şeyin diğer iki şeye bir yönden benzemesi anlamına gelen Teşbîhu Şey'eyni bi Şe'yeyni sanatı kullanılmış ve mızraklar gölgesinde savaşan sahabeler, çalılıklar arasındaki aslan yavrularına oyun oynama yönünden benzetilmiştir (el-Hillî, 1992, s. 231-232).

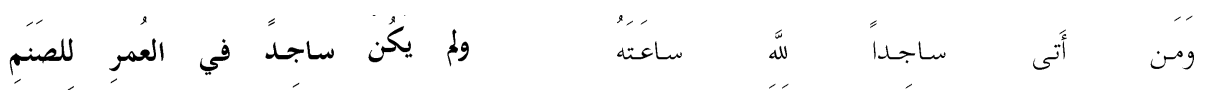

O, doğduğu saatte Allah'a secde ederek gelendir ve ömründe hiç puta secde eden olmamıştır.

Burada kullanılan sanat, üstü kapalı bir şekilde dokundurma veya iğneleme anlamına gelen Ta 'rîz'dir. el-Hillî, beyitin ikinci kısmında "ömründe puta hiç secde etmemiştî” diyerek müşrikleri iğnelemiştir (el-Hillî, 1992, s. 250-251).

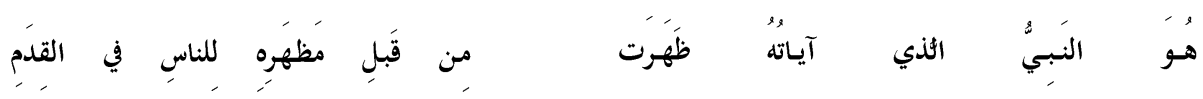


$O$, öyle bir peygamberdir ki insanlarca görülmeden çok önce mucizeleri ortaya çıkmıştır.

el-Hillî, bu beytinde ise okuyucuya yorum hakkı tanımayan, her şeyin yerli yerinde olduğu Tezhîb ve Te'dîb sanatını kullanmıștır. Yani bu sanatın kullanıldığı yerde okuyucu, şu lafız yerine bir diğeri olsaydı veya şu lafız önce veya sonra olsaydı gibi bir fikir sunamaz (el-Hillî, 1992, s. 259).

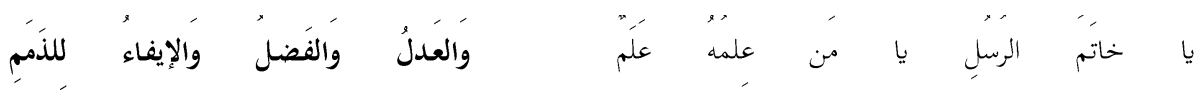

Ey son Peygamber! Ey ilmi, adaleti, üstünlükleri ve sorumluluklart yerine getirmesi bayrak gibi olan!

Burada kullanılan sanat, Siyâkatu'l-A 'dâd diye de anılan söze ahenk katmak için birkaç lafzı bir münasebetle birbirlerine bağlamak anlamına gelen $T a$ 'd $\hat{\imath} d$ sanatıdır. Bu beytin ikinci şatrında zikredilen ifadeler de عelimesiyle birbirlerine bağlanmıştır (el-Hillî, 1992, s. 306).

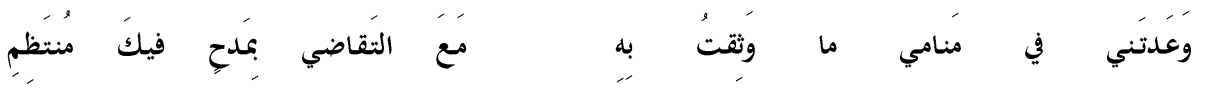

Senin için nazmedilecek bir methiye karşıllı̆̆ında, uykumda bana güvendiğim bir söz verdin.

$\mathrm{Bu}$ beyitte kullanılan sanat ise kişinin içerisinde bulunduğu hali kapalılıktan uzak, beliğ bir şekilde kolay lafızlarla dile getirmesi anlamına gelen Hüsnü'l-Beyân'dır (el-Hillî, 1992, s. 309).

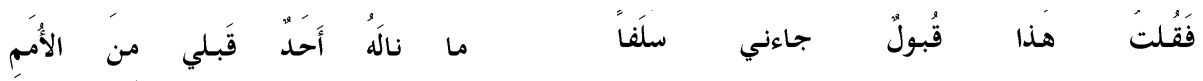

Ben de bu, benden önceki ümmetlerden hiç kimsenin nail olmadĭ̆ı öncü olarak gelen bir kabuldür dedim.

el-Hillî bu beytinde ise Teshîl veya Tazrîf diye de anılan, ifadede ince, kolay ve doğal lafizları düzgün bir şekilde ele almak anlamına gelen Sühulet sanatını kullanmıştır. Örnekte görüldüğü üzere beyit son derece sade ve anlaşılması kolaydır (el-Hillî, 1992, s. 311).

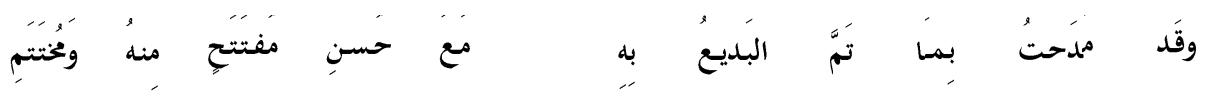

Kendisiyle bedî $i$ sanatların tamamlandiğı, başından sonuna güzelliklerle (dolu) bir methiye yazdim.

Burada kullanılan sanat ise sözü uzatmadan veya kısaltmadan insanların alışık olduğu lafız ve ifadelerle meramı bildirmek anlamına gelen Musâvât sanatıdır. Herhangi bir lafzın kaldırılması veya daha fazla açıklanmasıyla anlamın bozulduğu ya da başka bir ifade ile lafız ve mananın birebir uyuştuğu sanat anlamına da gelmektedir (el-Hillî, 1992, s. 322-323). 


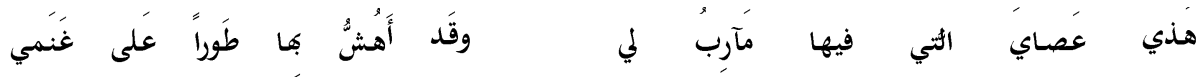

Bu (kaside), içerisinde isteklerimi bulunduran asamdır, ara sıra da onunla koyunlarıma yaprak dökerim.

$\mathrm{Bu}$ beyitte kullanılan sanat ise şiirde veya nesirde herhangi bir ayet-i kerîme veya hadis-i şerifin tamamının veya bir kısmının alıntı yapılması anlamına gelen İktibâs sanatıdır. Alıntı yapılan ayet ise Tâhâ suresinin Dedi ki: "O benim asâmdır. Ona dayanırım, onunla koyunlarıma yaprak silkelerim, ona

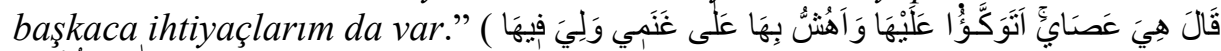
anlamındaki 18. ayetidir (el-Hillî, 1992, s. 326).

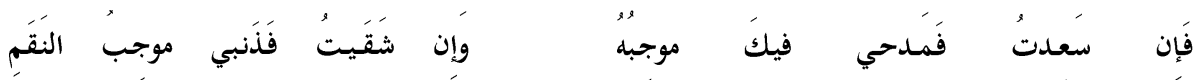

Ĕger mutlu olursam, sana olan methiyem onun sebebidir, ĕger mutsuz olursam da günahım bu felaketin sebebidir.

el-Hillî, bu meşhur bedî‘iyyesini Hüsn-i Hitâm/Hâtime/Makta' veya Berâ 'at-i Makta' gibi isimlerle de anılan Berâ 'at-i Hitâm sanatıla bitirmiştir. Bu sanattan amaç, Muktezâ-yı hale uygun bir şekilde sözün sonunun geldiğini güzel bir şekilde hissettirmektir (el-Hillî, 1992, s. 333-334).

\section{2.İbn Câbir el-Endelüsî}

Ebû Abdillâh Şemsüddîn Muhammed b. Ahmed b. Alî b. Câbir el-Hevvârî el-Endelüsî, h. 698'de (1299) el-Meriyye'de doğmuștur. el-Meriyye'de dönemin önemli hocaları olan Ebû'l-Hasan Ali b. Muhammed b. Ebû'lYa'îş’ten Kur'ân-1 Kerîm ve nahiv, Ebû Abdullah Muhammed ez-Zevâvî'den hadis, Ebû Abdullah Muhammed b. Saîd er-Rundî'den Mâlikî fikhına dair dersler okumuştur. Hicri 738 (1338) yılına gelindiğinde hac farizasını yerine getirmek için Endülüs'ten ayrılmıştır (es-Süyûtî, t.y., c. I, s. 34).

Kaynaklarda İbn Câbir'in hayatı hakkında verilen bilgiler oldukça az ve hac yolculuğunda tanışıp ömrünün sonuna kadar dostluk kurduğu şair ve edip er-Ru'aynî (ö. 779/1378) ile yapmış olduğu yolculuklar ve konaklamalar ile sınırlıdır. $\mathrm{Bu}$ ikili, tanışma sonrasındaki bütün vakitlerini beraber geçirmişlerdir. Hatta bu birliktelik, İbn Câbir ve er-Ru'aynî'nin, "el-A 'mâ ve el-Basîr" şeklinde anılmalarına sebep olmuştur. İbn Câbir, daha çok şiir er$\mathrm{Ru}$ 'aynî ise nesir alanında öne çıkan isimler olmuşlardır (es-Süyûtî, t.y., c. I, s. 34; ez-Ziriklî, 2002, c. V, 328).

Hac yolculuğuna müteakip yaklaşık on bir yıl boyunca Mısır, Hicaz, Dımaşk, Ba 'lebek, İskenderiye gibi ülke ve şehirlerde karşılaştıkları âlimlerden birlikte istifade etmişlerdir. Mısır'da bir süre kalarak Ebû Hayyân elEndelüsî'den dil ve edebiyat, Dımaşk'ta Yûsuf b. Abdurrahman el-Mizzî, İbn 
Kâmyâr ve Muhammed b. İbrâhim el-Cezerî'den hadis dersleri almışlar ve Ba'lebek'te Fâtıma bint Mûsâ b. Muhammed el-Yûnînî'den kıraate dair eşŞâț̣biyye adlı eseri okumuşlardır (Kılıç, 1999, c. XIX, s. 384-385; Durmuş, 2008, c. XXXV, s. 175-176).

İbn Câbir, hocası el-Mizzînin vefatından sonra 743/1342 yılında erRu'aynî ile birlikte Halep'e daha sonra ise ömrünün sonuna kadar ikâmet edeceği el-Bîre'ye (İlbîre) geçmiştir. Bu dönemde bölgede söz sahibi olan Artuklu sultanlarıyla ilişki kurmuş ve onlara methiyeler nazmederek büyük maddi kazançlar sağlamıştır. İbn Câbir, birçok didaktik şiir de nazmetmiş olmasına rağmen namını Hz. Peygamber için nazmetmiş olduğu Nebevî Methiyeler'ine borçludur. Şiirde mahir ve güçlü kabul edilen İbn Câbir, 780/1378 y1lında el-Bîre'de vefat etmiştir (İbnü'l-Hatîb, 1973, c. II, s. 330; esSüyûtî, t.y., c. I, s. 34; ez-Ziriklî, 2002, c. V, 328; Kılıç, 1999, c. XIX, s. 384385).

\section{1. el-Hulletü's-Siyerâ fî Medhi Hayri'l-Verâ}

el-Hulletü's-Siyerâ fì Medhi Hayri'l-Verâ isimli eser, İbn Câbir'in Hz. Peygamber'in methi için nazmetmiş olduğu 177 beyitten oluşan edebî sanatlarla örülü kasidesidir. Bu eser Bedî'iyyetü'l-'Umyân ve el-Bedî'iyye fî Medhi Hayri'l-Beriyye adlarıyla da anılmaktadır. İbn Câbir, bu bedî‘'iyyesinde birbirinden farklı 43 fakat cinâs çeşitleri de ayrı ayrı sayılırsa toplamda 50 farklı bedî sanat kullanmıştır. İbn Câbir, el-Hillî gibi mukaddimesinde veya bedî‘iyyesinin herhangi bir bölümünde bu kasideyi neden nazmettiğine dair bilgi vermemiştir. Fakat yaşadığı asrın ta 'lîmî/didaktik şiirlerin revaçta olduğu bir döneme rast gelmesi, bu durum hakkında kısmen de olsa bilgi vermektedir. Bu bilgiden hareketle, İbn Câbir'in bu meşhur bedî‘iyyesini nazmetme sebebi, o dönemde bir nevi gelenek haline gelen ve içerisinde çeşitli bedî‘ sanatlarını bulunduran (ta'lîmî/didaktik) bir tarzla Hz. Peygamber methiyesi ile Allah'a yakınlaşmak olabilir. İbn Câbir'in bu kasidesine yapılan en önemli şerh ise yakın arkadaşı er-Ruaynî tarafindan yapılan Tirâzu'l-Hulle fì Şifâ'i'l-Ğulle isimli eserdir (İbn Câbir, 1985, s. 9-10).

İbn Câbir, bu bedî'iyyesine geleneksel kaside üslubu ile başlayıp Hz. Peygamber'e ve onun yurduna olan özlemini dile getirdikten sonra, Hz. Peygamber'in güzel ahlakını geniş bir şekilde ele almış ve mucizelerinden çokça bahsetmiştir. Daha sonra ise gazvelerde gösterilen başarıları ele alan İbn Câbir, Hz. Peygamber'in ecdadını, Ehl-i Beyt'ini ve sahabeyi övmüştür. İbn Câbir, bedî‘iyyesini iyileşme temennisini belirtip şefaat ve eğer sözlerinde bir kusur var ise özürle affedilmeyi dileyerek sonlandırmıştır. İbn Câbir'in bu meşhur bedî‘iyyesinin bazı bölümleri şöyledir:

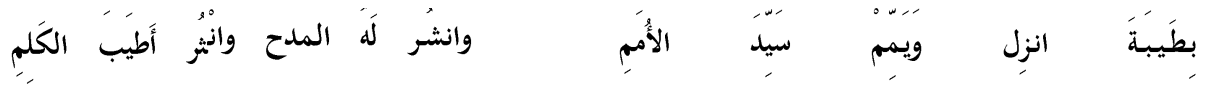


Taybe'de konakla ve milletlerin efendisine yönel, onun methiyesini herkese duyur ve sözlerin en güzelini serpiştir.

İbn Câbir, bu meşhur bedî‘iyyesine kulağa hoş gelen, sade lafızlarla, kapalılıktan uzak ve ortama uygun sözlerle güzel bir başlangıç yapmak anlamına gelen Berâ 'at-i Matla '/Hüsn-i İbtidâ' sanatını kullanarak başlamıştır. Aynı beyitte إنشُّ kelimelerinde harflerin sayısı, türü, harekesi veya sırasından herhangi birisinin eksik olması anlamına gelen Cinâs-ı Gayr-i Tâm kullanılmıştır (İbn Câbir, 1985, s. 28-29).

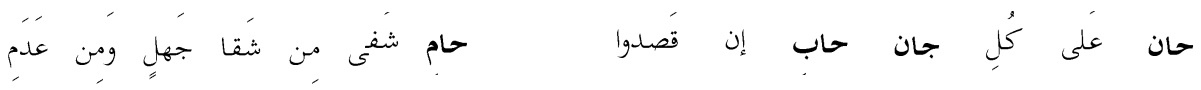

Ĕ̆er (kendisine) sı̆̆ınırlarsa bütün diz çöken suçlulara karşı şefkatlidir, yokluk ve cehaletin slkıntısinı gideren bir koruyucudur.

Bu beyitte kullanılan sanat Cinâs-ı Muzâri ' dir. Harflerin türlerinin farklı olup mahreçlerinin birbirine yakın olduğu cinâs türüdür (İbn Câbir, 1985, s. 32).

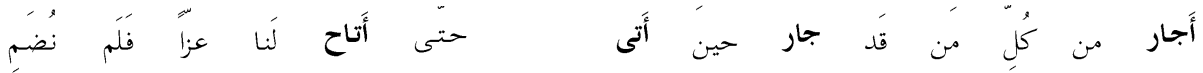

Geldiği vakit bütün zulmedenlerden kurtardı bizi hatta hiç ulaşamadı̆̆ımız bir izzet sağladı bize.

Burada ise cinâsın iki farklı çeşidi kullanılmıştır. Birincisi أَجارَ ve ifadelerinde görüldüğü üzere cinâsı oluşturacak kelimelerden her hangi birisinin ilk harfinin fazla olması anlamına gelen Cinâs-ı Merdûf; diğeri ise أَتاحَ ve ifadelerinde olduğu gibi harf fazlalığının kelimelerden herhangi birinin sonunda olması anlamına gelen Cinâs-ı Mutarref' dır (İbn Câbir, 1985, s. 35-36).

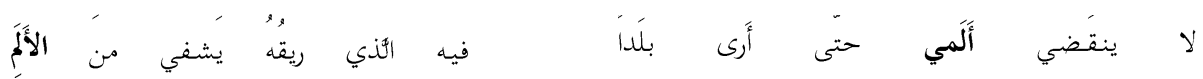

Tükürüğ̈̈ acıyı iyileştirenin içerisinde olduğu beldeyi görene kadar acım dinmez.

İbn Câbir, burada "sonu başa döndürmek" şeklinde bilinen ve şiirde beytin sonunda yer alan kelimeyi veya kelimeleri önceden tekrarlamak anlamında kullanılan Reddü'l-'Acüz 'alâ's-Sadr sanatını kullanmıştır. Ayrıca Hz. Peygamber'in tükürüğünün şifalı olması ile alakalı hadîs-i şeriften iktibâs yapıldığ1 söylenebilir (İbn Câbir, 1985, s. 51-52).

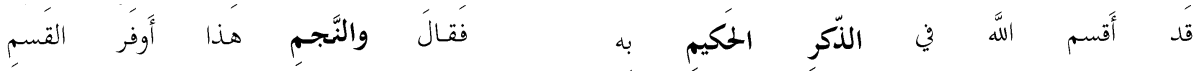

Allah, Kur'ân-ı Kerîm'de ona yemin etti ve dedi ki: Yıldız'a yemin olsun (وَ), bu da yeminin en bereketlisidir. 
Bu beyitte ise iktibâs yapılmaksızın nesri nazma çevirmek anlamına gelen 'Akd sanatı kullanılmıştır (İbn Câbir, 1985, s. 70-71). Beyitte görüldüğg̈ü üzere

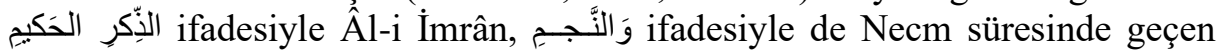
ayetlerden 'akd yapılmıştır.

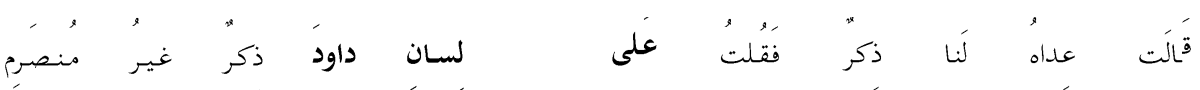

Düşmanları dedi ki: bizim bir anılmamız vardır, bu yüzden bende dedim ki: Davut'un diliyle olan anılmanız geçmiş değildir.

İbn Câbir, bu beyitte ise nazım veya nesirde meşhur bir olaya veya duruma

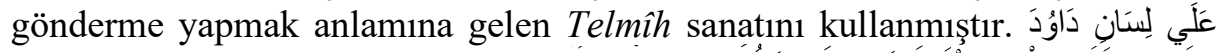

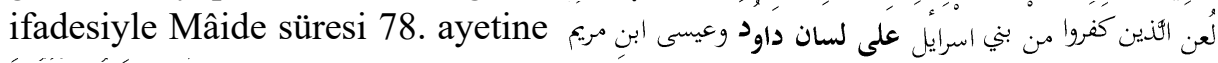

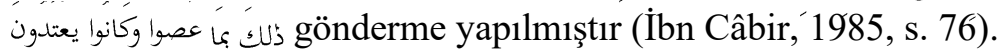

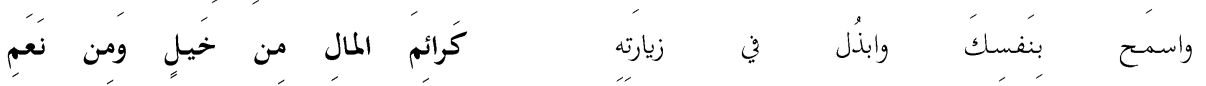

Kendin için gönülden ver, onun (Hz. Peygamber'in) ziyareti için nimetlerin atların ve malların en klymetlilerinden bahşet.

Burada kullanılan sanat, şiirde başkasına ait şiirden bir mısra veya bir beyit almak anlamına gelen Tazmîn sanatıdır. İbn Câbir de bu beyitinin ikinci şatrını Abbâsiler döneminin meşhur şairlerinden biri olan Şerîf er-Radî'den (ö. 406/1015) tazmîn etmiştir (İbn Câbir, 1985, s. 81).

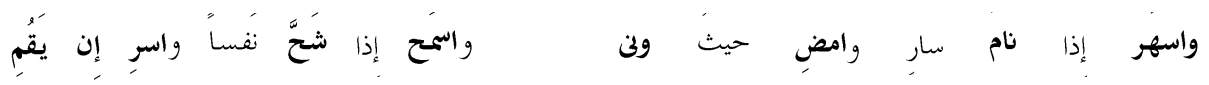

(Ziyarette) yürüyen uyursa sen uyanık ol, yllginlık gösterdiğinde sen ilerle, birisine cimrilik edilirse sen cömertlik yap, o dursa bile sen devam et.

Bu beyitte ise Mutâbakat, Tezât ve Tekâfu' gibi isimlerle de anılan ve anlam bakımından aralarında zitlik bulunan kelimeleri bir arada uyum içerisinde kullanmak anlamına gelen Tıbâk sanatı kullanılmıştır (İbn Câbir, 1985, s. 85).

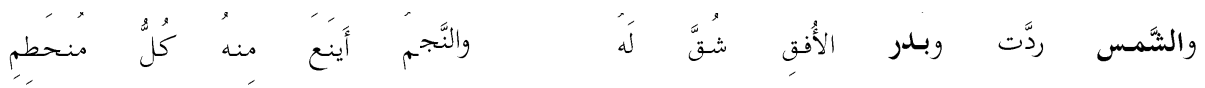

O'nun için güneş geri gönderildi ve ufuktaki dolunay yarıldl, bitkiler ve bütün zerre onunla olgunluğa ulaştı.

İbn Câbir, bu beyitte aralarında zıtlık dışında anlam yönünden bir ilişki bulunan kelimeleri bir arada kullanmak anlamına gelen Murâ ât-ı Nazîr sanatını kullanmıştır (İbn Câbir, 1985, s. 92). 


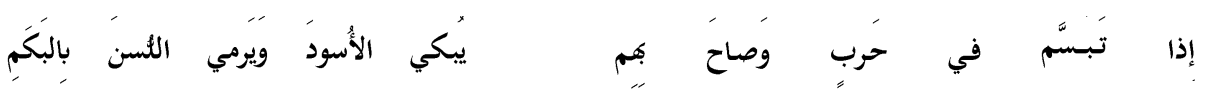

Savaşta tebessüm ettiğinde ve onlara seslendiğinde, aslanları ă̆latır, beliğleri dilsiz eder.

Burada kullanılan sanat ise şart ve cevap cümlelerindeki manaların birbirine eşit olması anlamına gelen Müzâvece/İzdivâc sanatıdır. Görüldüğü üzere beytin ilk kısmında iki şart cümlesi sunulmuş, ikinci kısmında ise iki cevap verilmiştir (İbn Câbir, 1985, s. 99).
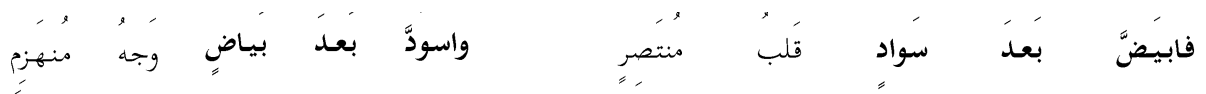

Galip gelenin kalbi karardıktan sonra beyazlad,, mağlup olanın yüzü ise beyazladıktan sonra karardl.

Bu beyitte Tard veya Tebdil olarak da anılan, bir cümle ya da mısradaki kelime gruplarının ters çevrilerek yer değiştirilmesi neticesinde yeni bir ifadenin oluşması anlamına gelen Aks sanatını kullanılmışıı (İbn Câbir, 1985, s. 101).

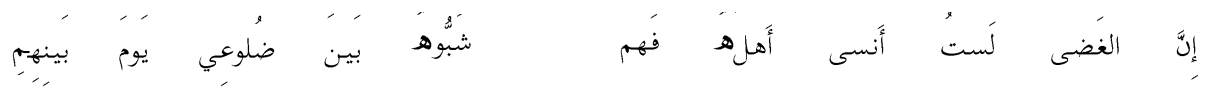

Seksek ăgact...Onların arasındayken kaburgalarımın arasında onu tutuşturduklarl için oranın ehlini unutacak değilim.

İbn Câbir, bu beytinde ise kelimenin iki zamirinden birisiyle bir anlamını, diğeriyle ikinci anlamının kastedilmesi anlamına gelen İstihdâm sanatını kullanmıştır. Örnekte görüldüğ̈ gibi birinci zamir, seksek ağacının ehline, ikinci zamir seksek ağacını tutuşturanlara dalalet etmektedir (İbn Câbir, 1985, s. 110).

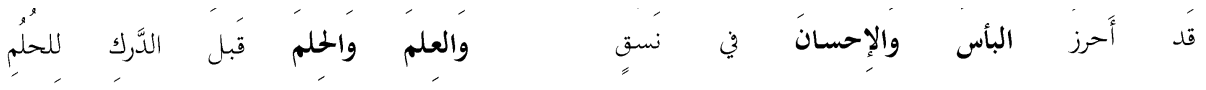

Yiğitliğe ve ihsana düzenli bir şekilde, ilme ve hilme ise rüştüne ermeden nail olmuştur.

Burada kullanılan sanat, birden fazla şeyi tek hüküm altında toplamak anlamına gelen Cem 'sanatıdır. Hz. Peygamber'in ilim, hilm, yiğitlik ve ihsan gibi güzel vasıfları, peygamberlik vazifesinden önce kendisine bağışlanmıştır hükmünde toplanmıştır (İbn Câbir, 1985, s. 115).

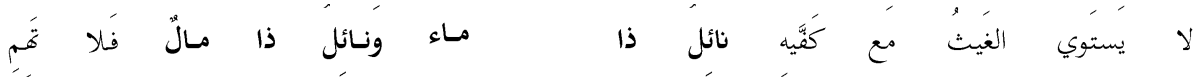

Avuçlarıyla (sunduğu) bereket aynı değildir, kimin elde ettiği sudur, kimin ki ise maldır, sen bilemezsin. 
$\mathrm{Bu}$ beyitte ise aynı türden olan iki durumun aslında aynı olmadığını ve aralarında fark olduğunu anlatmak için kullanılan Tefrîk sanatı kullanmıştır. Yani Hz. Peygamber'in elinden bir rahmet, bereket yağar ancak kimisi için sadece su kimisi için bir maldır (İbn Câbir, 1985, s. 116).

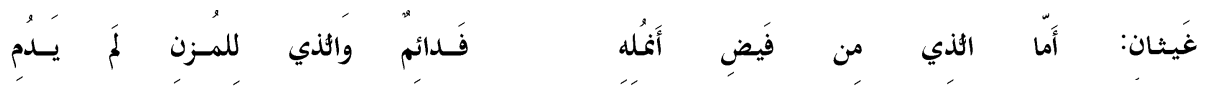

İki bereket vardır, parmak uçlarından olan süreklidir ancak bulutlardan olan devam etmedi.

İbn Câbir, bu beyitte Taksîm sanatını kullanmıştır. Bu sanatın özelliği zikredilen şeyin kısımlarına ayrılmasıdır. غَيَنْـان lafzı zikredilmiş ve sonrasında ikiye bölünmüştür (İbn Câbir, 1985, s. 117).

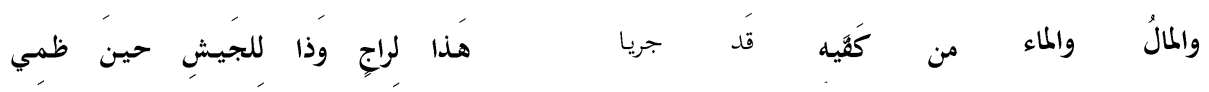

Mal ve su avuçlarından akmıştı, biri ümit eden için diğeri ise susadiğında ordu için.

Burada kullanılan sanat ise iki şey cem edildikten sonra farklı hükümlere bağlamak anlamına gelen Cem 'me 'a't-Taksîm sanatı kullanılmıştır. Beyitte görüldüğü üzere mal ve su $\mathrm{Hz}$. Peygamber'in avuçlarında toplanmış ve sonrasında ikisinin de farklı kişiler için olduğu ifade edilmiştir (İbn Câbir, 1985,

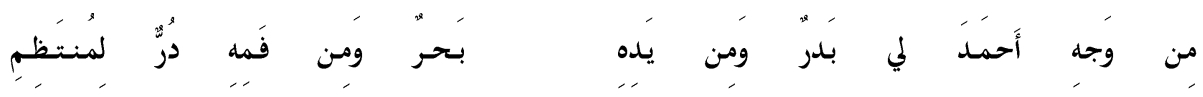

Ahmed'in yüzünden kaynakl bir dolunay halim, elinden kaynakl bir deniz halim, ăgzından kaynaklı dizili incilerim vardır benim.

$\mathrm{Bu}$ beyitte kullanılan sanat, insanın başka bir varlığa hitap ederek kendisini kastetmesi anlamına gelen Tecrîd sanatıdır. İbn Câbir de bu sanatı oldukça iyi kullanmış ve sahip olduğu bazı güzelliklerin aslında Hz. Peygamber'den kaynaklandığını dile getirmiştir (İbn Câbir, 1985, s. 122).

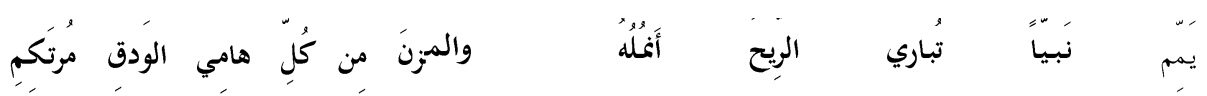

Parmak uçları rüzgârla ve kümeler halinde yağmur akıtan bulutlarla yarışan Nebi'ye yönel.

İbn Câbir, bu beyitte herhangi bir vasfi veya durumu zor bir dereceye veya aklen mümkün olmayacak dereceye çıkararak anlatmak anlamına gelen Mübâlağa sanatını kullanmıştır. Mübâlağa sanatının ise aklen ve adeten mümkün olan Teblî̆ çeşidiyle Hz. Peygamber'in parmaklarının bereket açısından rüzgâr ve bulutlar ile yarıştığını ifade etmiştir (İbn Câbir, 1985, s. 125). 


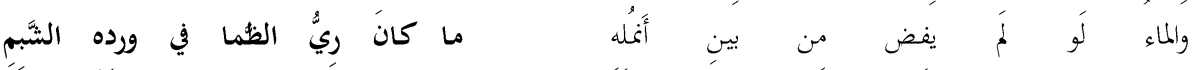

Ĕger su onun parmak uçlarından akmasaydl, susuzluğun giderilmesi soğuk kaynă̆ından olmazdl.

Burada kullanılan sanat ise ifadeye güzellik katmak amacıyla bir durumu gerçek sebebi dışında bir sebeple açıklamak anlamına gelen Hüsn-i Ta 'lîl' dir. İbn Câbir burada susuzluğun giderilmesinin sebebinin methiyesi gereğince Hz. Peygamber'in parmak uçlarına bağlamıştır (İbn Câbir, 1985, s. 130).

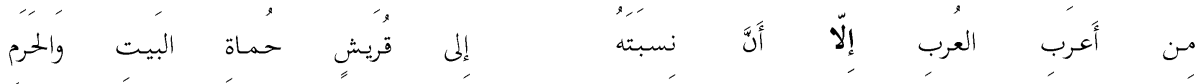

O, Araplar'in en Arap olanlarındandır ancak aynı zamanda onun soyu Harem 'in ve Kâbe 'nin koruyucuları olan Kureyş'e dayanmaktadır.

$\mathrm{Bu}$ beyitte kullanılan sanat yergi lafızları ile övgüyü pekiştirmek anlamına gelen ve İstisnâ' diye de anılan Te 'kîdu'l-Medh bimâ Yüşbihu'z-Zem sanatıdır. Farklı çeşitleri de olan bu sanatın bu beyitte kullanılan hali, kişinin bir vasıfla övüldükten sonra istisna edatı getirip okuyucuyu yergiyle devam edecek yargısına vardırıp daha fazla övmektir (İbn Câbir, 1985, s. 135).

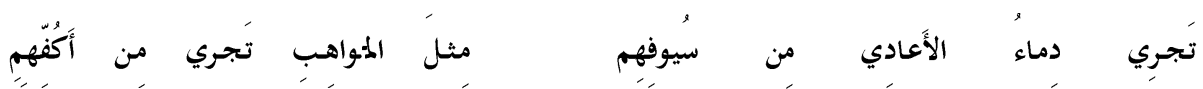

Bağışlarının avuçlarından akması gibi düşmanların kanı da onların kılıçlarından akar.

İbn Câbir, bu beytinde ise övgü veya yergi ifadesinin peşine doğal olarak aynı türden bir ifade getirmek anlamına gelen Istitbâ'sanatını kullanmıştır. Örnekte görüldüğü üzere birinci kısımda sahâbelerin bir özelliği övüldüğü için ikinci kısımda övgü ile devam etmiştir (İbn Câbir, 1985, s. 140).

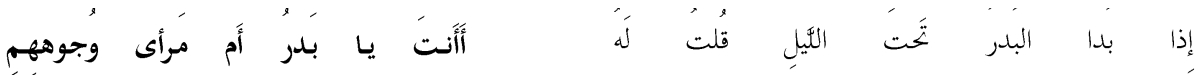

Gecenin karanlı̆̆ında dolunay göründüğ̈̈nde ona dedim ki: Ey dolunay! Sen misin yoksa onların yüzlerinin görüntüsü müsün?

$\mathrm{Bu}$ beyitte kullanılan sanat, bilinen bir şeyi bir nükteye bağlı olarak bilmiyormuş gibi ifade etmek veya bilmezden gelmek anlamına gelen Tecâhül$i$ 'Ârif' dir. İbn Câbir, burada bulutların arkasında dolunayı görmüş olmasına rağmen soru sorarak bilmiyormuş gibi davranmıştır (İbn Câbir, 1985, s. 144).

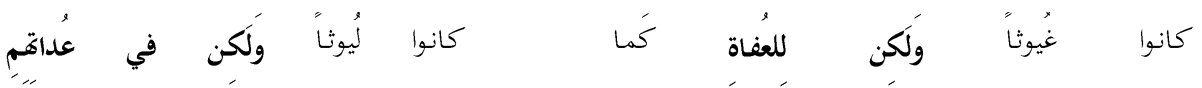

Onlar rahmet (yă̆mur) oldular ancak hoşgörülü olanlara, aynen düşmana karşı aslan oldukları gibi. 
Burada kullanılan sanat başkasının sözüne karşılık cevap mahiyetinde bir söz söylemek anlamında olan ve karşıdaki kişinin iddiasının aslında yanlış olduğunu bildirmek anlamında kullanılan el-Kavlu bi'l-Mûceb sanatıdır. İbn Câbir de genel olan ifadeleri özele indirerek bu sanatı kullanımıştır (İbn Câbir, 1985, s. 145).

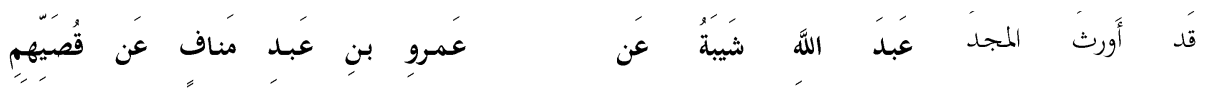

Şerefi-şanı Kusay'ları Amr b. Abdimenâf'a, Amr Şeybe'ye, o ise Abdullah'a miras bırakmıstır.

İbn Câbir, kasidesinin bu beytinde bir kimsenin ismini ve ecdâdını büyükten küçüğe veya küçükten büyüğe araya başka isim sokmadan sırasıyla zikretmek anlamına gelen İttirâd sanatını kullanmıştır (İbn Câbir, 1985, s. 147).

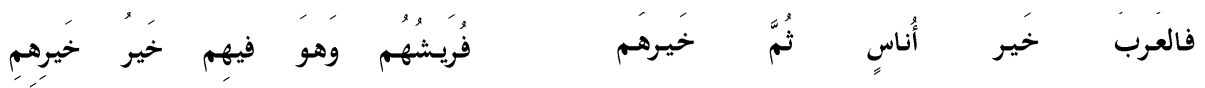

Araplar insanların en hayırlılarıdır, onların en hayırlıları ise Kureyşli olanlarıdır, o ise hayırlı olanların arasinda en hayırlı olanidır.

$\mathrm{Bu}$ beyitte, iktibâs yapılmaksızın nesri nazma çevirmek anlamına gelen

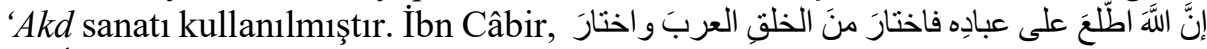

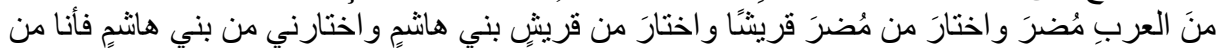
hadis-i şerifinden istifade ederek 'akd sanatını kullanmıştır (İbn Câbir, 1985, s. 148).

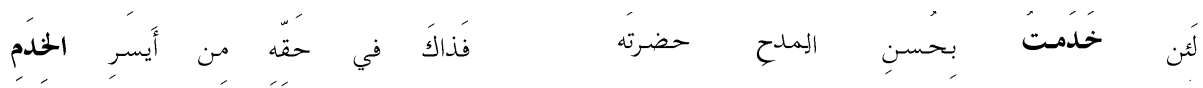

Ĕ̆er onun varlı̆̆ına medhin güzellikleriyle hizmet edebildiysem, şüphesiz bu ona uygunluk hususunda hizmetlerin en kolayıdır.

Burada kullanılan sanat, Cinâs-ı İktidâb, Cinâs-ı Muktadab ve Cinâs-ı Müştak gibi isimlerle de anılan Cinâs-ı İștikâk'tır. Bu cinâs çeşidinin şartı ise kök harfleri itibariyle iki lafzın aynı olmasıdır (İbn Câbir, 1985, s. 150).

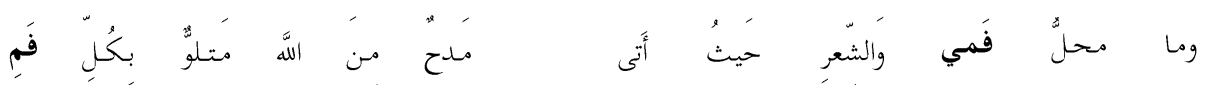

Her ă̆ız tarafindan okunan Allah'ın medhinin geldiği yerde benim ăgzımın ve şiirimin bir ehemmiyeti yoktur.

İbn Câbir, burada "sonu başa döndürmek" şeklinde bilinen ve şiirde beytin sonunda yer alan kelimeyi veya kelimeleri önceden tekrarlamak anlamında kullanılan Reddü'l- 'Acüz 'alâ's-Sadr sanatını kullanmıştır (İbn Câbir, 1985, s. 151).

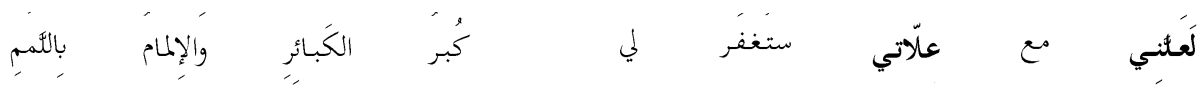


Ola ki, hastalıklarımla beraber küçük ve büyük günahlarım bağışlanır.

Bu beyitte kullanılan sanat, iki harfin kök harflerinin birbirine yakın olması sebebiyle cinâs-1 iştikâk'1 andırması anlamına gelen Cinâs-ı Müşấbehe sanatı kullanılmıştır. Ayrıca bu beyitte tıbâk ve cinas-1 iştikâk sanatları da kullanılmıştır (İbn Câbir, 1985, s. 152).

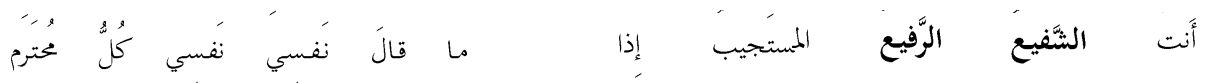

Bütün hatırı sayllanlar "nefsim, nefsim" dediği zamanda sen şefaat eden, saygin olan ve icabet edensin.

Burada ise cinâsı meydana getirecek olan lafizlarda bulunan harflerden en az birisinin türünün ve mahrecinin farklı olması anlamında kullanılan Cinâs-ı Lâhik sanatı kullanılmıştır (İbn Câbir, 1985, s. 152).

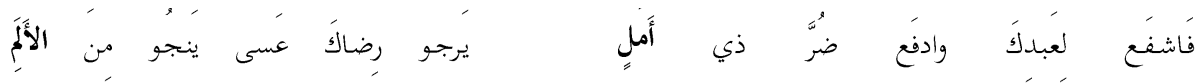

Kölene şefaat eyle ve ümit sahibinin sıkıntısını gider, o senin rızanı umuyor, ola ki sancidan kurtulur.

$\mathrm{Bu}$ beyitte kullanılan sanat, cinâsı oluşturacak lafizlarda harflerin sıralanışının farklı olması anlamına gelen Cinâs-ı Kalb sanatı kullanılmıştır (İbn Câbir, 1985, s. 152).

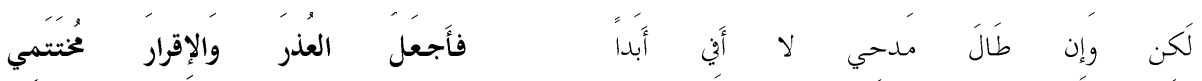

Ancak ĕger medhim uzamış olsa da asla hakkını tam veremedim, bu yüzden nihayete erdirmeyi ve özür diliyorum.

İbn Câbir, bedî‘iyyesini Hüsn-i Hitâm/Hâtime/Makta' veya Berâ‘at-i Makta' gibi isimlerle de anılan Hüsn-i İntihâ' sanatıyla bitirmiştir. Bu sanattan amaç, Muktezâ-yı hale uygun bir şekilde sözün sonunun geldiğini güzel bir şekilde hissettirmektir (İbn Câbir, 1985, s. 155).

\section{Sonuç}

Hz. Peygamber'in methetmek maksadıyla nazmedilen birçok şiir türü vardır. Bunlardan birisi de içerisinde övgü ifadelerinin bedî‘sanatlarla yoğrulduğu bedî‘iyyât şiirleridir. Bu tür şiirler, bazı edebiyatçılar tarafindan "inhitât" diye adlandırılan dönemin nadide eserlerindendir. Bedî‘iyyât şiirlerinin ilk kez kim tarafından nazmedildiği her ne kadar tartışmalı olsa da bu konuda akla ilk gelen isim Safiyyüddin el-Hillî’dir.

el-Hillî’nin bu türü belli bir sisteme oturtması, Arap şiirinde yeni bir yol açarak kendinden sonrakilere örnek teşkil etmesi ve kendisini bu türün mucidi olarak ilan etmesi de bu görüşü destekler mahiyettedir. Fakat Bûsîrî’nin el-Hillî 
üzerindeki etkisi de göz ardı edilmemelidir. Çünkü el-Hillî, kasidesini nazmetme sebebi olarak rüyasını zikrederken şartlara değinmemesi, bu türe benzer şeylerin daha önceden var olduğunu kanıtlar niteliktedir.

el-Hillî ve İbn Câbir'in kasidelerinde işlenen konular, birbirine oldukça fazla benzemektedir. Her iki şair de şiirlerine Hz. Peygamber'in yurduna duydukları özlemi dile getirerek başlamış ve sonrasında Hz. Peygamber'i, soyunu ve ashabını övmüş, Hz. Peygamber'in mucizelerini anlatmış, şifa talebinde bulunmuş ve eğer şiirlerinde bir kusur var ise af dileyerek şiirlerini bitirmiştir. Fakat bedî‘sanatları işleme şekilleri ve konuları ele alış biçimleri birbirlerinden oldukça farklıdır. el-Hillî, daha çok belâgat kitaplarında tasnif edilen bedî‘ sanatlarının sıralamasını esas alarak sayı yönünden daha fazla bedî‘ sanat işlemiştir. İbn Câbir, böyle bir kural gözetmemiş ve daha az sanat kullanmıştır. el-Hillî, lafzî sanatları kasidesinin ilk kısımlarında kullanırken İbn Câbir, daha çok son bölümlerde kullanmıştır. Konuların ele alınış biçimlerine bakıldığında ise duygusallık yönünden el-Hillî’nin İbn Câbir'e göre biraz daha sönük kaldığı ya da başka bir ifadeyle el-Hillî’nin sistem yönünden İbn Câbir'in ise Endülüslü olması hasebiyle duygu yönünden daha başarılı olduğu söylenebilir.

Bedî‘iyyat şiirlerinin genel manada amacına ulaştı̆̆ ve Arap edebiyatına olumlu katkılar sağladığı söylenebilir. Yani bu tür şiirler ile Hz. Peygamber methedilmiş, bedî‘ sanatlar geniş kitlelere ulaştırılmış, öğretilmiş ve kalıcı olmaları sağlanmıştır. Ayrıca bu şiirler, başta sahipleri olmak üzere birçok kişinin şerh yazmasına vesile olmuştur.

\section{Kaynakça}

Akçay H. (2021). "Safiyuddîn el-Hillî’nin Artûkiyyât Şiirleri”, International Journal of Mardin Studies. Cilt:2, Say1: 1, s. 56-66.

Bulut, A. (2015). Belâgat Terimleri Sözlüğü. İstanbul: M. Ü. İlahiyat Fafültesi Vakfi Yayınları.

Dayf, Ş. (1965). el-Belâ̆ga: Tatavvur ve Târîh (9. Baskı). Kâhire: Dâru'lMe'ârif.

Durmuş, İ. "Ruaynî”, DIA, İstanbul, 2008, C. XXXV, s. 175-176.

Ebû Zeyd, A. (1983). el-Bedî 'iyyât fî̀'l-Edebi'l- 'Arabî (Neşetuhâ-TatavvuruhâEseruhâ)(1. Baskı). Beyrût: 'Âllemu'l-Kutub.

el-Fîrûzâbâdî, Ebû't-Tâhir Mecduddîn Muhammed b. Ya'kûb b. Muhammed. (2008). el-Kâmûsu'l-Muhît. thk. Enis Muhammed eş-Şâmî ve Zekeriyyâ Câbir Ahmed. Kâhire: Dâru'l-Hadîs. 
el-Hillî, Ebü'l-Mehâsin (Ebü'l-Fazl, Ebü'l-Berekât) Safiyyüddîn Abdülazîz b. Serâyâ b. Alî et-Tâî. (1992). Şerhu'l-Kâfìyeti'l-Bedî 'iyye fì 'Ulûmi'lBelâğa ve Mehâsinu'l-Bedî‘. thk. Nesîb Neşâvî, Beyrut: Dâru Sâdır.

İbn Câbir, Ebû Abdillâh Şemsüddîn Muhammed b. Ahmed b. Alî el-Hevvârî elEndelüsî. (1985). el-Hulletü's-Siyerâ fî Medhi Hayri'l-Verâ. thk. Ebû Ali Zeyd. Beyrût: 'Alemu'l-Kutub.

İbn Manzûr, Ebû'l-Fadl Cemâlüddîn Muhammed b. Mükerrem. (h. 1400). Lisânü'l-'Arab. thk. Ahmed Fâris. C. XV. Beyrût: Dâru Sâdır.

İbnü'l-Hatîb, Ebû Abdillâh Zü'l-Vizâreteyn Lisânuddîn Muhammed b. Abdillâh b. Saîd es-Selmânî el-Endelüsî. (1973). el-ïhâta fî Ahbâri Ğırnâta (2. Baskl). thk. Muhammed Abdullah 'İnân. C. IV. Kâhire: Mektebetu Hâncî.

el-İskenderî, A. ve Diğerleri. (1936). el-Mufassal fî Târîhi'l-Edebi'l-'Arabî. Kâhire: Matba'atu'l-Emîriyye.

K1lıç, H. "Bedîyyât", DİA, İstanbul, 1992, C. V, s. 323-324. “İbn Câbir”, DİA, İstanbul, 1999, C. XIX, s. 384-385.

Kılıçl1, M. "Hillî, Safiyyüddin”, DİA, İstanbul, 1998, c. XVIII, s. 41-44.

el-Kütübî, Ebû Abdillâh Salâhuddîn Muhammed b. Şâkir b. Ahmed. (1973). Fevâtü'l-Vefeyât. thk. İhsân 'Abbâs. C. V. Beyrût: Dâru Sadır.

Muhammed M. S. (h. 1417). el-Medâ'ihu'n-nebeviyye hattâ Nihâyeti'l- 'Asri'lMemlûkî. Dımaşk: Dâru'l-Fikr.

Mübârek, Z. (1953) el-Medâ'ihu'n-Nebeviyye. Beyrût: Dâru'l-Mehacceti'lBeyzâ'.

el-Mühendis, M. V. K. (1984). Mu'cemu'l-Mustalahâti'l-'Arabiyye fi'l-Luğa ve'l-Edeb. Beyrût: Mektebetü Lübnân.

er-Receb, Îmân 'İvâd. (2020). "Bedî‘iyyâtu'l-'Asri'l-Memlûkî beyne'l-Bedî' ve'l-Medîhi'n-Nebevî”, Mecelletu Cîli'd-Dirâsâti'l-Edebiyye ve'lFikriyye, Y11:7, Say1:60, s. 99-117.

Selîm, M. R. (1962). 'Asru Selâtîni'l-Memâlîk ve Nitâcuhu'l- 'Ilmî ve 'l-Edebî (1. Baskı). C. VIII. Kâhire: Dâru'l-Kitâbi'l-'Arabî.

es-Seyyîd, Hemdân Sa'd. (2008). el-Bedî 'iyyât fí'l-Edebi'l- 'Arabî (el-Mefhûmen-Neş'e- el-Ğaraz-el-Binâ'). Tanta, byy. 
Suzan, Y.-Yavuz A. (2018). “Safiyyuddîn el-Hillî’nin el-Kafîyetu'lBedî‘iyyesi”, Batman Üniversitesi İslami İlimler Fakültesi Hakemli Dergisi, Cilt: 2, Say1: 2, s. 26-44.

es-Süyûtî, Ebû'l-Fazl Celâlüddîn Abdurrahmân b. Ebî Bekr b. Muhammed elHudayrî. (1964). Buğyetu'l-Vu 'ât fí Tabakâtu'l-Luğaviyyîn ve'n-Nuhât (1. Baskl). thk. Muhammed Ebû'l-Fazl İbrâhîm. C. II. Kâhire: Matba'atu 'Îsâ, t.y.

Yanık, N. H. (2014). Edebi Bilgiler ve Aruz, Erzurum: Fenomen Yayınları.

ez-Ziriklî, Ebû Gays Muhammed Hayrüddîn b. Mahmûd b. Muhammed b. Alî b. Fâris ed-Dımaşkî. (2002). el-A 'lâm (15. Baskı). C. VIII. Beyrût: Dâru'1'İlm li'l-Melâyîn. 